\title{
PERTUMBUHAN ANAK UMUR 6-24 BULAN DENGAN RIWAYAT BAYI BERAT LAHIR RENDAH (BBLR)
}

\author{
Desi Darojatul Kamilah ${ }^{1}$, Widya Maya Ningrum² \\ Prodi D III Kebidanan, Fakultas Ilmu Kesehatan, Universitas Galuh, Indonesia \\ desikamilah@gmail.com ${ }^{1}$,Widyamayaningrum@gmail.com ${ }^{2}$ \\ (Diterima 15-05-2020; disetujui 20-05-2020; dipublish 27-05-2020)
}

\begin{abstract}
ABSTRAK
Bayi Berat Lahir Rendah (BBLR) adalah bayi berat lahir rendah, kurang dari 2500 gram tanpa memandang masa gestasi. Di Puskesmas Singaparna tahun 2016-2017 2016 yaitu 964 bayi dengan bayi BBLR sebanyak 71 bayi (5,1\%). tahun 2017 jumlah bayi lahir 593 dengan BBLR 45 $(8,2 \%)$ total BBLR 116 orang. Jenis Penelitian ini merupakan penelitian kuantitatif metode deskriptif, populasi penelitian ini adalah Anak yang Berumur 6-24 Bulan yang ada di wilayah kerja Puskesmas Singaparna Kabupaten Tasikmalaya. Pengambilan sampel penelitian ini menggunakan teknik Purposive Sampling yaitu sebanyak 29 orang. Instrument pengumpulan data menggunakan lembar kuisioner. Hasil penelitian mengenai Pertumbuhan Anak dengan riwayat BBLR di wilayah kerja Puskesmas Singaparna memiliki pertumbuhan berat badan anak yang sesuai umur sebanyak 25 orang $(86,2 \%)$ dan tidak sesuai umur sebanyak 4 orang $(13,8 \%)$, pertumbuhan panjang badan anak yang sesuai umur sebanyak 22 orang $(75,9 \%)$ dan tidak sesuai umur sebanyak 7 orang $(24,1 \%)$, pertumbuhan lingkar kepala anak yang sesuai umur sebanyak 28 orang $(96,6 \%)$ dan tidak sesuai umur sebanyak 1 orang $(3,4 \%)$. Kesimpulan dari penelitian ini adalah Pertumbuhan Menurut Standar Antropometri termasuk pada kategori Pertumbuhan Sesuai dengan Umur, dengan ini disarankan bidan untuk lebih memperhatikan Skrining Pemeriksaan Anak Khususnya yang mempunyai riwayat BBLR sehingga terpantau pertumbuhannya dan akan Terdeteksi jika terjadi penyimpangan pertumbuhan
\end{abstract}

Kata kunci: BBLR, Pertumbuhan

\begin{abstract}
Low birth weight babies (LBW) are infants with low birth weight, less than 2500 grams regardless of gestational period. In Singaparna Public Health Center 2016-2017 2016, 964 babies with LBW infants were 71 babies (5.1\%). in 2017 the number of babies born was 593 with LBW 45 (8.2\%) total LBW of 116 people. This type of research is a descriptive quantitative research method, the population of this study are children aged 6-24 months in the working area of Singaparna Health Center, Tasikmalaya Regency. Sampling of this study uses purposive sampling technique that is as many as 29 people. Instrument of data collection using questionnaire sheet. The results of the study on the growth of children with a history of low birth weight in the working area of Singaparna Community Health Center had an appropriate growth in body weight of children as many as 25 people $(86.2 \%)$ and age inappropriate as many as 4 people $(13.8 \%)$, appropriate length of child body growth age of 22 people $(75.9 \%)$ and age inappropriate as many as 7 people (24.1\%), the growth of the head circumference of the appropriate age of 28 people $(96.6 \%)$ and age inappropriate as many as 1 person $(3,4 \%)$. The conclusion of this study is that Growth According to Anthropometric Standards belongs to the Age-Based Growth category, hereby it is recommended that midwives pay more attention to Screening for Special Screening for Children who have a LBW history so that their growth is monitored and will be detected if growth deviations occur.
\end{abstract}

Keywords: LBW, Growth 
PENDAHULUAN

Berdasarkan World Health Orgnization (WHO) hampir semua (98\%) dari lima juta kematian neonatal terjadi di negara berkembang. Lebih dari dua pertiga kematian itu terjadi pada periode neonatal dini (0-7 hari), yang umumnya dikarenakan Berat Bayi Lahir (BBL) kurang dari 2500 gram. (1) Salah satu penyebab kematian bayi yang angka kejadianya paling tinggi adalah bayi berat lahir rendah (BBLR). BBLR adalah bayi berat lahir rendah, kurang dari 2500 gram tanpa memandang masa gestasi. Berat Badan lahir rendah adalah berat bayi yang ditimbang dalam 1 jam setelah lahir. BBLR seringkali menyebabkan komplikasi, baik itu terjadi secara langsung setelah persalinan maupun untuk jangka panjang. Komplikasi jangka panjang antara lain gangguan pertumbuhan, gangguan perkembangan, gangguan penglihatan dan pendengaran (2) Gangguan pertumbuhan yang biasa terjadi yaitu postur pendek, postur tubuh tinggi, berat badan kurang, makrosefalus dan mikrosefalus. Anak yang terlahir dengan bayi berat lahir rendah (BBLR) lebih berpotensi stunting dibandingkan anak yang terlahir dengan berat badan lahir normal ${ }^{(3)}$

Penelitian yang dilakukan oleh Nengsih menunjukan adanya hubungan antara berat badan lahir rendah (BBLR) dengan pertumbuhan anak. Hasil dari penelitiaan tersebut mengatakan bahwa anak dengan riwayat BBLR memiliki risiko untuk mendapatkan ganguan pertumbuhan sebesar $54,2 \%$ dan dari 24 responden yang pertumbuhanya normal $83,3 \%$ tidak memiliki riwayat kelahiran BBLR. ${ }^{(4)}$

Menurut laporan Riset Kesehatan Dasar (Riskesdas) tahun 2013, prevalensi BBLR di Indonesia mengalami penurunan dari $11,1 \%$ di tahun 2010 menjadi $10,2 \%$ di tahun 2013 (Kemenkes, 2013). Dikuti dari Dinas Kesehatan Jawa Barat angka bayi baru lahir dengan BBLR pada tahun 2016 sebesar $2,2 \%{ }^{(5)}$

Berdasarkan data dari Dinas Kesehatan Jawa Barat bayi baru lahir dengan BBLR pada tahun 2016 mencapai 2,2\% dan di kabupaten Tasikmalaya ditentukan adanya kasus BBLR pada tahun 2016 yaitu sebanyak 943 kasus dari 30.986 bayi (32,8\%). Berdasarkan studi pendahuluan yang dilakukan di Puskesmas Singaparna terdapat kasus BBLR pada tahun 2016 yaitu sebanyak 71 kasus dari 943 bayi (7,4\%). Dan pada tahun 2017 yaitu sebanyak 45 kasus dari 593 bayi baru lahir (7,5\%). Pada tahun 2016 kejadian BBLR di Puskesmas Singaparna merupakan tertinggi dibandingkan puskesmas lain yang ada di Kabupaten Tasikmalaya, Sedangkan pada tahun 2017 merupakan tertinggi kedua setelah Puskesmas Leuwisari.

Fase balita merupakan Fase yang sangat kritis dalam upaya menciptakan sumber daya manusia yang berkualitas. Fase ini disebut sebagai periode emas golden period dimana sel-sel otak sedang 
Pertumbuhan Anak Umur 6-24 Bulan dengan Riwayat Bayi Berat Lahir Rendah (BBLR)

mengalami pertumbuhan dan

perkembangan yang optimal

\section{METODE PENELITIAN}

Jenis penelitian ini adalah kuantitatif dengan metode deskriptif yaitu memberikan gambaran pertumbuhan balita usia 6-24 bulan dengan riwayat bayi berat lahir rendah (BBLR) di wilayah kerja puskesmas singaparna kabupaten Tasikmalaya tahun 2016-2017. Penelitian ini dilaksanakan pada bulan Mei-Juni 2018 selama dua minggu, di wilayah kerja Puskesmas Singaparna.

Populasi dalam penelitian ini adalah anak 6-24 bulan dengan riwayat BBLR di wilayah kerja Puskesmas Singaparna tahun 2016 sebanyak 71 bayi dan pada tahun 2017sebanyak 45anak, sehingga total anak yg mengalami BBLR 116 anak. Pengambilan sampel dalam penelitian ini dilakukan dengan menggunakan teknik purposive sampling dengan kriteria responden berumur kurangdari 24 bulan. dan wali responden bersedia mengikutsertakan anaknya Berdasarkan pengambilan data maka jumlah sampel dalam penelitian ini adalah 29 orang. Instrumen yang digunakan dalam penelitiaan ini adalah kuisioner untuk bertanya identitas responden, dan format isian untuk mengetahui status kesehatan responden, Dacin untuk mengukur berat badan responden, Infantometer untuk mengukur panjang badan responden, pita ukur (metlin) untuk mengukur lingkar kepala responden, Pengolahan data sesuai dengan usia koreksi.

\section{HASIL PENELITIAN DAN \\ PEMBAHASAN}

Hasil Penelitian

\begin{tabular}{|c|c|c|}
\hline \multicolumn{3}{|c|}{$\begin{array}{l}\text { 1. Pertumbuhan Berat Badan } \\
\text { dengan Riwayat BBLR }\end{array}$} \\
\hline $\begin{array}{c}\text { Berat Badan } \\
\text { Bayi }\end{array}$ & Frekuensi & Presentase \\
\hline $\begin{array}{l}\text { Anak dengan } \\
\text { berat badan } \\
\text { sesuai umur }\end{array}$ & 25 & 86,2 \\
\hline $\begin{array}{l}\text { Anak dengan } \\
\text { berat badan } \\
\text { tidak sesuai } \\
\text { umur }\end{array}$ & 4 & 13,8 \\
\hline Jumlah & 29 & 100 \\
\hline
\end{tabular}

Berdasarkan tabel diatas dapat dilihat bahwa dari 29 Responden, diketahui bahwa sebagian besar resonden mengalami pertumbuhan berat badan sesuai umur yaitu sebanyak 25 orang $(86,2 \%)$ dan sebagian kecil dari responden memiliki pertumbuhan tidak sesuai umur sebanyak 4 orang $(13,8 \%)$.

\begin{tabular}{lcc}
$\begin{array}{l}\text { 2. Pertumbuhan Panjang } \\
\text { Piwayat BBLR }\end{array}$ & & \\
$\begin{array}{c}\text { Panjang } \\
\text { Padan Bayi }\end{array}$ & Frekuensi & Presentase \\
Bangan \\
\hline $\begin{array}{c}\text { Anak dengan } \\
\text { panjang badan } \\
\text { sesuai umur }\end{array}$ & 22 & 75,9 \\
$\begin{array}{c}\text { Anak dengan } \\
\text { panjang badan } \\
\text { tidak sesuai } \\
\text { umur }\end{array}$ & 7 & \\
\hline Jumlah & & \\
\hline
\end{tabular}

Berdasarkan tabel diatas dapat dilihat bahwa dari 29 Responden, diketahui bahwa sebagian besar resonden mengalami pertumbuhan panjang badan sesuai umur yaitu sebanyak 22 orang $(75,9 \%)$ dan sebagian kecil dari responden memiliki pertumbuhan panjang badan tidak sesuai umur sebanyak 7 orang $(24,1 \%)$. 
3. Pertumbuhan Lingkar Kepala dengan Riwayat

Panjang Badan

Bayi

Anak dengan

lingkar kepala

sesuai umur

Anak dengan

lingkar kepala

tidak sesuai

umur

$$
\text { Jumlah }
$$

100

Berdasarkan tabel diatas dapat dilihat bahwa dari 29 Responden, diketahui bahwa sebagian besar responden mengalami pertumbuhan lingkar kepala sesuai umur yaitu sebanyak 28 orang $(96,6 \%)$ dan sebagian kecil dari responden memiliki pertumbuhan lingkar kepala tidak sesuai umur sebanyak 1 orang(3,4\%) mikrosefalus.

\section{Pembahasan}

Dalam Penelitian ini penulis menghadapi beberapa keterbatasan yang dapat mempengaruhi kondisi dari penelitian yang dilakukan, adapun keterbatasan tersebut antara lain pada saat pengambilan data sebagian wali responden ada yg tidak bersedia mengikutsertakan dengan alasan sudah pernah mengikuti karena terkait etika penelitian maka jumlah responden 29 orang.

Penelitiaan ini menunjukan bahwa jumlah kelahiran BBLR di wilayah kerja Puskesmas Singaparna pada tahun 20162017 kategori prematur lebih banyak dibanding dengan IUGR. Berdasarkan hasil penelitian yang telah dilakukan diketahui bahwa dari 29 ibu responden sebagian besar orang tua responden berumur 20-35 tahun $(82,8 \%)$ dan sebagian kecil berumur $>35$ tahun $(6,9 \%)$. Hal ini menunjukan bahwa sebagian besar orang tua bayi berada pada kelompok usia produktif.Kondisi usia ibu yang masih muda sangat membutuhkan zatzat gizi untuk pertumbuhan biologiknya. Kebutuhan untuk pertumbuhan biologik ibu dan kebutuhan untuk janin dalam kandungannya merupakan dua hal yang pemenuhannya berlangsung melalui mekanisme yang kompetitif, di mana keadaan janin berada di pihak yang lemah. Hal inilah yang menyebabkan bayi lahir dengan kondisi berat badan yang rendah (Suriani, 2010). Pendidikan Ibu responden sebagian besar berpendidikan SD sebanyak 16 orang $(55,2 \%)$ dan sebagian kecil berpendidikan PT sebanyak 1 orang $(3,4 \%)$.

Tingkat pendidikan merupakan faktor yang mendasari pengambilan keputusan. Pendidikan menentukan kemampuan menerima dan mengembangkan pengetahuan dan teknologi. Semakin tinggi pendidikan ibu akan semakin mampu mengambil keputusan bahwa pelayanan kesehatan selama hamil dapat mencegah gangguan sedini mungkin bagi ibu dan janinnya. Pendidikan juga sangat erat kaitannya dengan tingkat pengetahuan ibu tentang perawatan kehamilan. Untuk pekerjaan orang tua anak, sebagian besar orang tua responden tidak bekerja sebanyak 28 orang $(90,3 \%)$ dan sebagian kecil bekerja sebagai buruh $(3,4 \%)$. Secara tidak langsung penghasilan ibu hamil akan memengaruhi kejadian BBLR, karena umumnya ibu-ibu dengan penghasilan keluarga rendah akan mempunyai intake makanan yang lebih rendah baik secara kualitas maupun secara kuantitas, yang akan berakibat terhadap rendahnya status gizi ibu hamil tersebut. Keadaan status gizi ibu yang buruk berisiko 
Pertumbuhan Anak Umur 6-24 Bulan dengan Riwayat Bayi Berat Lahir Rendah (BBLR)

melahirkan bayi dengan BBLR dibandingkan dengan bayi yang dilahirkan ibu dengan status gizi baik. Hal senada juga diungkapkan oleh Penghasilan berperan dalam meningkatkan risiko kejadian BBLR. Beberapa alasan diantaranya adalah kesulitan dalam pemenuhan kebutuhan kalori, disamping juga karena ibu-ibu yang miskin sebelumnya juga kurang gizi.Hal ini menujukan bahwa pekerjaan berhubungan dengan status ekonomi keluarga sehingga berpengaruh terjadap kejadian BBLR. ${ }^{(6)}$

Hasil penelitian tentang paritas menunjukan bahwa sebagian orangtua anak baru melahirkan 1 kali (primipara) sebanyak sebanyak 15 orang $(51,7 \%)$ dan sebagian kecil multipara sebanyak 14 orang $(48,3 \%)$. kemungkinan mempunyai risiko melahirkan BBLR pada responden dengan paritas1 atau $>3$ anak adalah 1,24 kali lebih besar dibandingkan responden dengan paritas 2-3 anak. Ibu hamil dengan paritas lebih dari tiga kali, umumnya akan mengalami gangguan dan komplikasi dalam masa kehamilannya. Komplikasi yang sering terjadi adalah gangguan pada plasenta, yaitu abruptio plasenta (plasenta tidak seluruhnya melekat pada dinding uterus), plasenta letak rendah dan solutio plasenta. Komplikasi ini mempunyai dampak terhadap pertumbuhan dan perkembangan janin, yang selanjutnya akan menyebabkan kejadian BBLR.Hal ini menunjukan bahwa BBLR bisa terjadi pada jumlah paritas yang sedikit. Berdasarkan hasil penelitian yang telah dilakukan diketahui bahwa sebagian besar umur responden 15-17 bulan sebanyak 7 orang
$(24,1 \%)$ dan sebagian kecil umur 24 bulan sebanyak 1 orang $(3,4 \%)$.

Pertumbuhan ialah bertambahnya ukuran dan jumlah sel serta jaringan intraseluler, bertambahnya ukuran fisik dan stuktur tubuh dalam arti sebagian atau keseluruhan. pertumbuhan dapat diukur secara kuantitatif yaitu dengan mengukur berat badan, panjang badan, lingkar kepala untuk mengetahui pertumbuhan fisik. ${ }^{(4)}$ Hasil penelitian menunjukan bahwa dari 29 responden mengalami pertumbuhan yang tidak sesuai dengan umur sebanyak $(13,8 \%)$ yang. anak yang dilahirkan BBLR menyebabkan kondisi yang tidak menguntungkan dalam pertumbuhan. Penelitian ini menunjukan bahwa kualitas manusia sangat ditentukan oleh kualitas janin semasa dalam kandungan. Bayi dengan BBLR akan berdampak pada jangka panjang kehidupanya sehingga anak akan mengalami gangguan pertumbuhan.

Faktor lainya yang dapat mempengaruhi pertumbuhan pada anak adalah kekurangan asupan nutrisi atau gizi. Asupan makanan bergizi amat penting untuk proses pertumbuhan. Zat gizi yang diperlukan adalah karbohidrat, protein, vitamin, dan mineral. Jika nutrisi yang dikonsumsi tidak adekuat, maka akan berakibat buruk terhadap pertumbuhanya. ${ }^{(7)}$ Tumbuh kembang bayi diperlukan zat makanan yang adekuat, selain itu adanya penyakit penyerta saat balitapun bisa menyebabkan terjadinya gangguan pertumbuhan.

Berdasarkan hasil penelitiaan yang telah dilakukan mengenai pertumbuhan 
panjang badan diketahui bahwa dari 29 Responden, diketahui bahwa sebagian besar resonden mengalami pertumbuhan panjang badan sesuai umur yaitu sebanyak 22 orang $(75,9 \%)$ dan sebagian kecil dari responden memiliki pertumbuhan panjang badan tidak sesuai umur sebanyak 7 orang $(24,1 \%)$. Dampak dari bayi yang memiliki berat lahir rendah akan berlangsung dari generasi ke generasi, anak dengan BBLR akan memiliki ukuran antropometri yang kurang pada perkembangannya. Hasil penelitian yang dilakukan oleh Mugni et al, 27 menunjukkan bahwa berat lahir merupakan prediktor yang signifikan dalam menentukan status pendek pada bayi usia 12 - 60 bulan, anak dengan BBLR yang diiringi dengan konsumsi makanan yang tidak adekuat, pelayanan kesehatan yang tidak layak, dan sering terjadi infeksi pada masa pertumbuhan akan terus mengakibatkan terhambatnya pertumbuhan.

DanUntuk pertumbuhan lingkar kepala diketahui bahwa sebagian besar responden mengalami pertumbuhan lingkar kepala sesuai umur yaitu sebanyak 28 orang $(96,6 \%)$ dan sebagian kecil dari responden memiliki pertumbuhan lingkar kepala tidak sesuai umur sebanyak 1 orang(3,4\%).Mikrosefali adalah gangguan sistem saraf langka yang menyebabkan kepala bayi menjadi kecil dan tidak berkembang, yang membuat otak anak berhenti tumbuh ${ }^{(8)}$

BBLR mengakibatkan komplikasi di masa yang akan datang. Komplikasi jangka panjang yang disebabkan oleh BBLR salah satunya adalah gangguan pertumbuhan. Gangguan pertumbuhan fisik meliputi gangguan pertumbuhan diatas normal dan gangguan pertumbuhan dibawah normal. Bila grafik berat badan anak diatas normal kemungkinan anak mengalami obesitas atau kelainan hormonal.

Sedangkan, apabila grafik berat badan dibawah normal kemungkinan anak mengalami kurang gizi, menderita penyakit kronis atau kelainan hormonal. Lingkar kepala juga menjadi salah satu parameter yang penting dalam mendeteksi gangguan pertumbuhan dan perkembangan. ${ }^{(9)}$

Berat lahir pada umumnya sangat terkait dengan pertumbuhan dan perkembangan jangka panjang. sehingga dampak lanjutan dari BBLR dapat berupa gagal tumbuh (Grouth faltering). Seorang bayi yang lahir dengan BBLR akan sulit dengan mengejar ketertinggalan pertumuhan awal. Pertumbuhan yang tertinggal dari yang normal akan menyebabkan anak tersebut menjadi stuntng

Tidak semua anak yang lahir dengan riwayat BBLR akan mengalami gangguan pertumbuhan hal ini terutama jika BBLR mendapatkan penanganan yang tepat pada saat persalinan, neonatus, masa bayi dan masa balita sehingga anak dengan BBLR tersebut tidak mengalami komplikasi, mendapat asupan gizi yang adekuat dan tidak disertai penyakit penyerta. Prognosis BBLR tergantung dari berat ringannya masalah perinatal, masa gestasi, berat badan lahir, keadaan sosial ekonomi, pendidikan orang 
Pertumbuhan Anak Umur 6-24 Bulan dengan Riwayat Bayi Berat Lahir Rendah (BBLR)

tua, perawatan pada saat kehamilan, persalinan dan nifas (pengaturan suhu lingkungan, pencegahan infeksi, penanganan gangguan pernafasan) d11.

Dari hasil penelitiaan yang telah dilakukan berat badan yang tidak sesuai umur sebanyak 4 orang dengan kategori 3 IUGR, 1 prematur. untuk pertumbuhan panjang badan yang tidak sesuai dengan umur terdapat 7 orang anak dengan kategori 5 IUGR, 2 prematur. dan untuk pertumbuhan lingkar kepala terdapat 1 orang dengan kategori IUGR. dari uraian tersebut dapat disimpulkan bahwa responden yang mengalami gangguan pertumbuhan banyak kategori IUGR karena pada BBLR dengan IUGR pada saat kehamilanya sudah terdapat gangguan pertumbuhan,yang terjadi bermingguminggu sampai berbulan-bulan sebelum bayi lahir. Sehingga berat, panjang dan lingkaran kepala dalam proporsi yang seimbang, akan tetapi keseluruhannya masih di bawah masa gestasi yang sebenarnya ${ }^{(2)}$

Berdasarkan uraian diatas, peneliti dapat mengemukakan bahwa pertumbuhan anak tidak hanya melihat dari riwayat anak saat lahir seperti BBLR, tetapi juga dipengaruhi oleh asupan gizi yang diterima oleh anak setelah diluar kandungan. Kemudian kemungkinan anak belum mendapatkan imunisasi juga dapat menghambat pertumbuhan anak, dikarenakan daya tahan tubuh anak menjadi berkurang. Oleh karena itu, penting bagi anak untuk mendapatkan imunisasi untuk memberikan kekebalan pada anak sehingga terhindar dari penyakit- penyakit. Selain itu, seringnya ibu memeriksa anaknya ke posyandu akan mempengaruhi pertumbuhan bayi karena dengan seringnya ibu datang ke posyandu pertumbuhan anak akan lebih terpantau. Sealain itu, pemberian susu formula dan MP ASI pada anak akan mempengaruhi pertumbuhan anak.

\section{SIMPULAN}

Anak dengan riwayat BBLR di wilayah kerja Puskesmas Singaparna memiliki pertumbuhan berat badan anak yang sesuai umur sebanyak 25 orang $(86,2 \%)$ dan tidak sesuai umur sebanyak 4 orang $(13,8 \%)$. Anak dengan riwayat BBLR di wilayah kerja Puskesmas Singaparna memiliki pertumbuhan panjang badan anak yang sesuai umur sebanyak 22 orang $(75,9 \%)$ dan tidak sesuai umur sebanyak 7 orang (24,1\%). Anak dengan riwayat BBLR di wilayah kerja Puskesmas Singaparna memiliki pertumbuhan lingkar kepala anak yang sesuai umur sebanyak 28 orang $(96,6 \%)$ dan tidak sesuai umur sebanyak 1 orang $(3,4 \%)$.

\section{DAFTAR PUSTAKA}

1. Simbolon D. Berat Lahir Dan Kelangsungan Hidup Neonatal Di Indonesia Birth Weight And Neonatal Survival In Indonesia. 2015;(95).

2. Proverawati. Berat Badan Lahir Rendah (BBLR). Nuha Medik. Yogyakarta; 2010. 24-30 P.

3. Halodoc. Alasan Stunting Dapat Sebabkan Mikrosefali Pada Anak. 2018; 
Desi Darojatul Kamilah \& Widya Maya Ningrum

4. Khayati YN. Hubungan Berat Badan Lahir Dengan Pertumbuhan Dan Perkembangan. 2019;2(September):5863.

5. Dinas Keseahatan Provinsi. Profile Kesehatan. Jawa Barat; 2016.

6. Simarmata OS. Hubungan Kualitas Pelayanan Antenatal Terhadap Kejadian Bayi Berat Lahir Rendah Di Indonesia (Analisis Data Sekunder Survei Demografi Dan Kesehatan Indonesia. 2010;

7. Tahun U, Gunawan G, Fadlyana E, Rusmil K, Penelitian B. Hubungan Status Gizi Dengan Perkembangan Anak 1-2 Tahun. 2011;13(2):142-6.

8. Luh Ayu Purnami DKS. Analisis Faktor Resiko Kejadian Stunting Pada Anak Di Posyandu Banjar Pasek. Midwinerslion. 2018;3(2).

9. Chamidah AN. Deteksi Dini Gangguan Pertumbuhan Dan Perkembangan Anak. J Pendidik Khusus. 2009;5. 